Volume 9. No. 4, April 2021

International Journal of Emerging Trends in Engineering Research

Available Online at http://www.warse.org/IJETER/static/pdf/file/ijeter25942021.pdf

https://doi.org/10.30534/ijeter/2021/25942021

\title{
Studies on variations in Physico-chemical Properties of Mustard Seeds during Drying and Fluidized bed Drying Kinetics
}

\author{
Bhasker V, Basava Rao, $\mathrm{V} \mathrm{V}^{1}$ \\ University College of Technology, Osmania University \\ Hyderabad-500 007, Telangana, India. \\ ${ }^{1}$ Email:Profbasavarao_1964@yahoo.com
}

\begin{abstract}
Proper drying methods can prevent the damage of food grains by changing in physic-chemical properties and minimize the spoilage during storage and improve the nutrition quality of grain. Thus proper drying methods are very important to choose based on operating conditions and cost. In present work, the typical variations in physico-chemical properties of mustard seeds obtained from Varshakonda Village in Telangana State were investigated during drying in Hot Air Oven, Tray Drier and Fluidized Bed drier. Removal of moisture during fluidized bed drying is observed very effective. Also, nutritional properties like fat, protein, phosphorous \& iron contents were found to decrease considerably low during drying in Fluidized bed comparatively in hot air oven and tray drier. Therefore, mustard seeds can effectively dried in Fluidized Bed. The fluidization characteristics of mustard seeds under different operating conditions were investigated in order to find out best drying method to dry mustard seeds.
\end{abstract}

Key words: Mustard Seeds, Drying, Fluidized Bed Drier, Tray Dryer, Hot Air Oven, Moisture, Physico-Chemical Properties, Drying Kinetics

\section{INTRODUCTION}

In India Mustard Seeds are grown in Rabi Season. Seed will germinate at a soil temperature as low as $40^{\circ} \mathrm{F}$. Brown and oriental Mustard Seeds (Brassica Juncea) are used as sources of oil, vegetable, condiments and fodder. Also, they are a popular addition to dishes such as vegetable, beans, pastries and pickles. Two different types of Mustard are grown in Telangana State; larger size $(2.15 \mathrm{~mm})$ and smaller size $(1.9 \mathrm{~mm})$. Generally perceived as health benefiting spice, mustard seeds are indeed very rich in phyto-nutrients, minerals, vitamins, and anti-oxidants. Being one of the chief oil seeds, mustards are indeed very high in calories; $100 \mathrm{~g}$ of seeds provide 508 calories.
After harvesting, the Mustard Seeds usually contain 18 to $20 \%$ of moisture and subsequently they attain $16.5 \%$ moisture before taking for drying. Mustard seeds are considered to be dried below $9 \%$ seed moisture for safe, long-term storage. Physico-Chemical Properties of Mustard seeds may change and thus calories and nutritional values may effect if proper drying method is not chosen. Therefore, suitable drying methods are very much important for safe and long term storage without tamper of nutrition values.

After harvesting, the Mustard Seeds usually contain 18 to $20 \%$ of moisture and subsequently they attain $16.5 \%$ moisture before taking for drying. Mustard seeds are considered to be dried below $9 \%$ seed moisture for safe, long-term storage. Physico-Chemical Properties of Mustard seeds may change and thus calories and nutritional values may effect if proper drying method is not chosen. Therefore, suitable drying methods are very much important for safe and long term storage without tamper of nutrition values.

Drying is the universal method of removing moisture which is the oldest most common method. High moisture promotes the development of insects and molds that are harmful. Further, the delay in drying, incomplete drying or ineffective drying reduces the quality. Drying is usually done to remove the moisture in controlled manner. Even though many traditional methods are available like sun drying, hot air oven and tray drying, they are highly inefficient and consume high energy as well as cost. Therefore, an effective drying method is necessary Compared with other drying techniques, fluidized bed drying offers many advantages. When hot air is blown over the grain in fluidized bed, heat is transferred to its surface and the latent heat of vaporization causes water to evaporate. Water vapour diffuses through a boundary film of air. This creates a region of lower vapour pressure at the surface of the grain and a water vapour gradient is established from the most interior part of the grain to the dry air.

Okey Francies Obi et al [1] evaluated moisture content determination procedures for pearl millet using air oven method. The moisture content of the pearl millet samples varied from 11 to $41 \%$ (wet basis). Chandrasekhar Srinivasakannan [2] studied drying kinetics of Mustard in 
Fluidized Bed and the drying rate was found to increase significantly with increase in temperature and with flow rate of the heating medium, while decrease with increase in solids holdup. Hajidavalloo and Hamdullahpur [3] experimentally investigated the drying of Mustard seeds and found that the inlet air temperature had an important effect on the magnitude of the drying rate, while the gas velocity and bed hold-up did not show significant contributions to the drying rate.

Sandeepa et al [4] studied the drying kinetics of sorghum seeds under the operating parameters such as temperature, flow rate of the drying medium, and solids holdup. The drying rate was found to increase significantly with increase in temperature and marginally with flow rate of the heating medium and to decrease with increase in solids holdup. The drying rate was compared with various simple exponential time decay models and the model parameters were evaluated. The experimental data were also modeled using Fick's diffusion equation. Bhasker and Basava Rao [5] investigated experimentally drying kinetics of millets in a fluidized bed dryer of having $5 \mathrm{~cm}$ ID and $50 \mathrm{~cm}$ height cylindrical fluidized bed column. The various operating conditions like air velocity $(1.27,1.06$ and $0.848 \mathrm{~m} / \mathrm{s})$, temperature $(40,50$, $\left.60^{\circ} \mathrm{C}\right)$ and Solid holdup $(0.125 \mathrm{~kg}, 0.150 \mathrm{~kg}$ and $0.175 \mathrm{~kg})$ were maintained. The drying kinetics in the fluidized bed was found at the fluidization conditions and it was observed that the voidage increases steadily with the increase in air velocity at any particular maintained temperature.

Simonyan et al [6] studied some physical properties of Sorghum within the moisture range of 8.89 to $16.5 \%$ and found the grain particle density decreased with increasing moisture content. It is found that drying is a complex operation involves transfer of heat and mass along with several inherent processes, such as physical or chemical transformations which, in turn, may cause changes in physic-chemical properties and product quality as well as the mechanisms of heat and mass transfer based on method of drying.

\section{MATERIALS AND METHODS}

\subsection{Materials}

Mustard seeds were obtained from farms of Varshakonda Village, Jagityala District, Telangana State, India where Mustards are highly harvested. The diameters of Male and Female Mustard Seeds are observed to be 2.15 and $1.9 \mathrm{~mm}$. The Physico-Chemical Properties were measured by using electronic balance, Vernier calliper, Screw gauge, Desiccators, Muffle furnace, Soxhlet apparatus, Kjeldhal apparatus, Atomic Absorption Spectroscopy. The experimental study on drying of mustard seeds conducted by using Tray dryer (Figure 1), Hot air Oven (Figure 2), and Fluidized Bed Dryer (Figure 3),

\subsubsection{Fluidized Bed Dryer}

The fluidized bed used for the drying of mustard seeds, is consisting a cylindrical fluidized bed column of $5 \mathrm{~cm}$ internal diameter and $50 \mathrm{~cm}$ height. The gas distributor was $2 \mathrm{~mm}$ thick with $2 \mathrm{~mm}$ perforations having $13 \%$ free area. A fine wire mesh was spot welded over the distributor plate to arrest the flow of solids from the fluidized bed in to the air chamber. Air blower with volumetric discharge capacity of $200 \mathrm{~m}^{3} / \mathrm{h}$ was used. Air velocity from the Compressor was measured using a Rota meter, before being heated and fed to the fluidization column, through the air chamber. The electrical heater consisted of a multiple drying element each of $2 \mathrm{KW}$ rating. The wet bulb and dry bulb temperatures were measured using two different thermometers. The schematic diagram and photograph of the experimental set up were shown in Figure 3

\subsection{Methods}

Mustard seeds, initially separated from broken, foreign matter, split and deformed seeds before the samples were prepared for the experiment. Initial moisture content of Mustard seeds, was determined by hot air oven method at $105^{\circ} \mathrm{C}$. Moisture content can be expressed in two ways, dry and wet basis. The equations used to estimate moisture content are given below:

\section{Moisture percentage by wet basis $=($ Mass of water/Mass of sample) $\times 100$}

\section{Moisture percentage by dry basis $=($ Mass of water/Mass of dry solid) $\times 100$}

It is observed that the initial average moisture content in mustard seeds is around $16.5 \%$ (wet basis)

In this study Mustard seeds were dried using three different drying techniques (Hot Air Oven, Tray Drier and Fluidized bed drying) at a temperature of $60^{\circ} \mathrm{C}$ to obtain the best possible quality dried product

\subsubsection{Hot air Oven Drying}

It is electrically operated equipment used to dry heat sterilize samples at temperature between $50^{\circ} \mathrm{C}$ to $300^{\circ} \mathrm{C}$ which requires exposure time up to 2 hours depending upon the temperature employed .The Oven was pre-heated to required temperature and then the samples in petriplate dishes were placed in oven. The weights of the sample were collected at every $30 \mathrm{~min}$ until a constant weight was reached. The process was done by taking sample of $5 \mathrm{~g}$ at a temperature of $60^{\circ} \mathrm{C}$.

\subsubsection{Tray Drying}

The dryer was pre-heated to required temperature and then the samples of $100 \mathrm{~g}$ each were spread in thin layers on the trays. 
Once the drying process started, the weights of the sample were collected at every 30 min until a constant weight was reached. The process was done by taking sample of $100 \mathrm{~g}$ at a temperature of $60^{\circ} \mathrm{C}$.

\subsubsection{Fluidized Bed Drying}

Air at desired temperature and velocity was allowed to flow through the fluidization column. A known quantity of the millet with known initial moisture content was introduced in to the column after ensuring the steady temperature and air velocity. The fluidization gas velocity was decided based on the minimum fluidization velocity of the millet. Fluidization velocities of approximately 1.5 to 2 times the minimum fluidization velocity were chosen for the experiments. The air to the fluidization column come from the air compressor and the air velocity is maintained by using a Rota meter. The temperature in the column was maintained by using the electrical heater. Drying of millet seeds is taking place in fluidized bed, so at every one minute wet bulb and dry bulb temperatures of inlet and outgoing air were noted down. This procedure is continued till steady state reading in temperatures is attained. The experiments were repeatedly conducted for different temperatures, velocities and different weights.

Table 1: Experimental conditions and Mustard seeds Properties used in the study

\begin{tabular}{|c|c|}
\hline Name of Material & $\begin{array}{c}\text { Mustard } \\
\text { (Brassica juncea) }\end{array}$ \\
\hline Shape of Material & Spherical \\
\hline Size, dp X 103, m & $2.15 \& 1.90$ \\
\hline Particle density, kg/m3 & 1100 \\
\hline Temperature of fluidizing air, ${ }^{\circ} \mathrm{C}$ & $40,50 \& 60$ \\
\hline Fluidizing air velocity, $\mathrm{m} / \mathrm{s}$ & $0.044,0.059 \& 074$ \\
\hline Solid holdup, $\mathrm{kg}$ & $175,150, \& 125$ \\
\hline
\end{tabular}

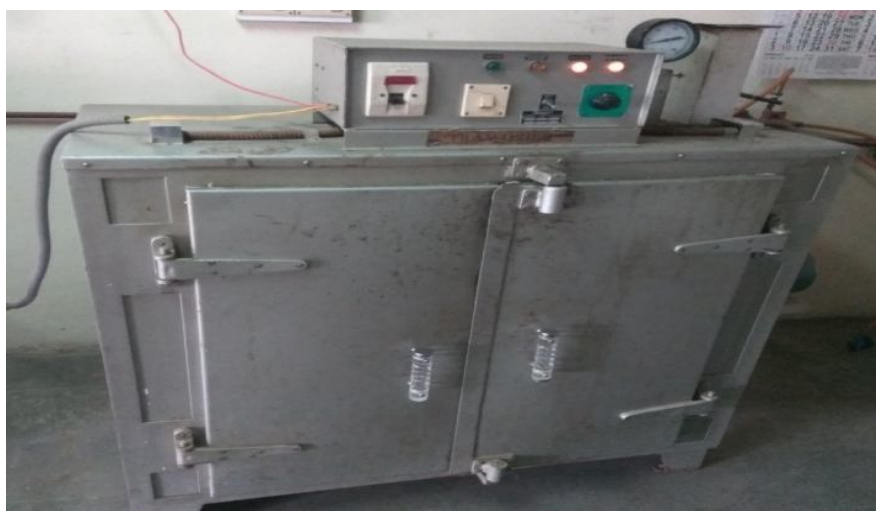

Fig 1 Tray Dryer

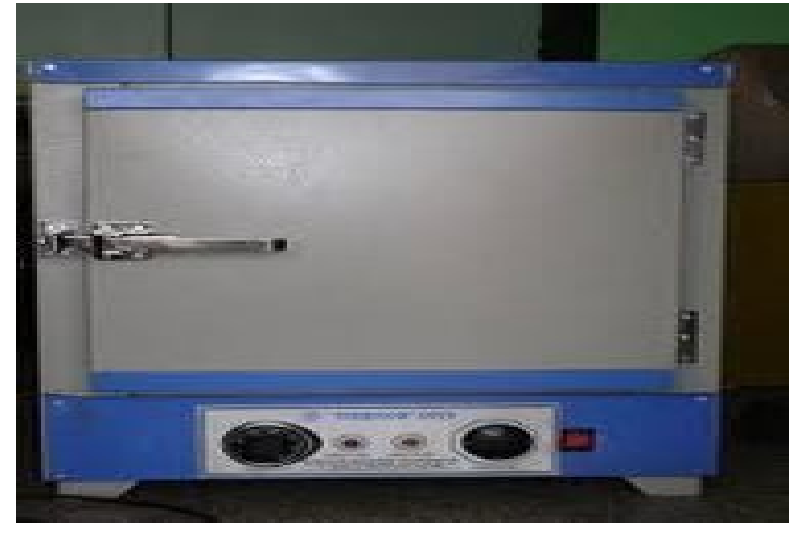

Fig 2 Hot Air Oven

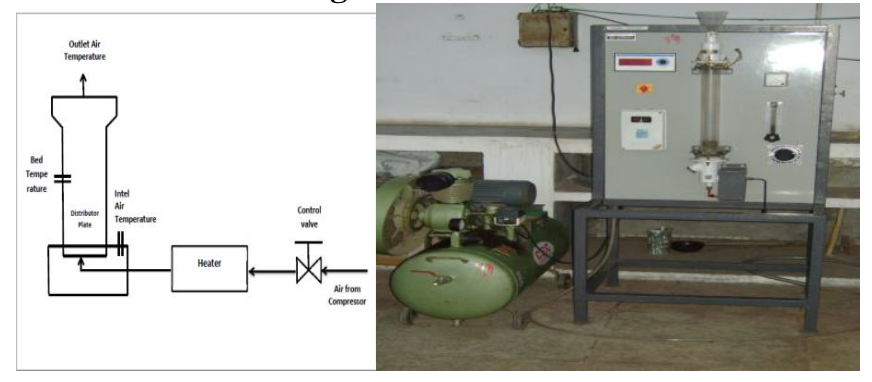

Fig 3: Fluidized Bed Dryer

\subsection{Physico-Chemical Analysis}

The physico-chemical properties were estimated using the following method;

\subsubsection{Estimation of Ash (\%)}

Five gram sample was weighed into a previously weighed silica crucible. It was then turned to carbonized form when silica crucible was burn at about $550^{\circ} \mathrm{C}$ for six hours in the muffle furnace to get complete white colour ash and then allowed it to cool in the furnace. The crucible was transferred to desiccator and weighed as possible to prevent moisture absorption process

$\%$ Ash content $=$ weight of ash

Original weight of sample $\times 100$

\subsubsection{Estimation Of Protein Content}

The principle of method involves the estimation of total nitrogen content in food and conversion of nitrogen to protein assuming that all nitrogen in food is present as protein and using a conversion factor based on the percentage of nitrogen in food. Weigh $1 \mathrm{gm}$ of sample and place in digestion tube of instrument and add $25 \mathrm{ml}$ of concentrated sulphuric acid. Then add $10 \mathrm{gm}$ of catalyst mixture. Adjust the temperature to $370^{\circ} \mathrm{C}$ and keep for digestion for 4-6hrs till the solution becomes blue in colour. Remove the tube from the digestion then cool the samples. Place $25 \mathrm{ml}$ of standard $0.1 \mathrm{~N}$ boric acid solution or $0.1 \mathrm{~N}$ sulphuric acid in the titration receiver flask (250ml conical flask) and place it in the distillation unit. 
Bhasker V et al., International Journal of Emerging Trends in Engineering Research, 9(4), April 2021, 479 - 484

Attach the tube containing digested sample to the distillation unit and press the start button to effect the metered addition of $40 \%$ sodium hydroxide solution and to initiate the steam distillation when the receiver platform falls and the distillation stops. Remove the flask and add 5 drops of methyl red indicator solution and titrate with $0.1 \mathrm{~N} \mathrm{HCl}$ solution to yellow colour end point if boric acid is used or $0.1 \mathrm{~N} \mathrm{NaOH}$ if $0.1 \mathrm{~N}$ sulphuric acid is used and indicator is phenopthalein, to carry out a blank determination.

\section{Conversion factor $\mathrm{F}=\mathbf{1 0 0 / \%}$ of nitrogen}

$\%$ of Nitrogen = (sample titer value - blank $) \times \mathrm{N}$ of $\mathrm{HCl} \mathrm{x}$ $14 \times 100 /($ weight of sample $\times 1000$ )

\section{Protein $\%=$ nitrogen $\% \mathrm{x}$ conversion factor}

\subsubsection{Estimation of Fat $(\%)$}

Fat content in the sample was estimated by Soxhlet extraction method. Moisture free sample was transferred to thimble which was then fixed into a stand and transferred to a pre-weighed Soxhlet beaker. The beaker was filled with petroleum ether. The beaker was then attached to Soxhlet apparatus and the sample was extracted for two hours at $60^{\circ} \mathrm{C}$. At the same temperature the ether was evaporated for two hours after extraction. At the end of four hours the ether left was dried in hot oven at $100^{\circ} \mathrm{C}$ for 30 minutes. The beaker was then cooled in desiccator and weighed. It gave the amount of ether soluble fat present in the sample.

\section{\% Fat content $=\quad$ weight of fat extract $\times \mathbf{1 0 0}$ weight of sample taken}

\subsubsection{Estimation of Crude Fiber (\%)}

Fat free samples were used for determination of crude fibre. Crude fibre is the organic residue which remains after the food sample has been treated under standardized condition with petroleum sprit, boiling dilute sulphuric acid, boiling dilute hydroxide solution and alcohol. About $3 \mathrm{~g}$ fat free residue was taken and then transferred to the digestion flask. $200 \mathrm{~mL}$ boiling sulphuric acid was added and immediately the flask was connected to condenser. Heated the flask and boiled it by frequently rotating for $30 \mathrm{~min}$, maintained the volume with hot water. Then it is filtered through filter cloth in a fluted funnel. The residue was washed on cloth with hot water or potassium sulphate solution, and returned the residue to digestion flask by washing with hot water, $200 \mathrm{ml}$ boiling sodium hydroxide was added and boiled for $30 \mathrm{~min}$. The volume was adjusted with boiling water, filtered it through the muslin cloth and the residue free of alkali was washed. The residue was transferred into crucible and washed with 15 $\mathrm{ml}$ alcohol and the crucible was dried at $130^{\circ} \mathrm{C}$ for $2 \mathrm{~h}$. The crucible was cooled in desiccator and weighed. The crucible was ignited in the furnace at $600^{\circ} \mathrm{C}$ for $30 \mathrm{~min}$ then cooled and weighed. The loss in weight represented the crude fibre
Crude fiber $=[100-($ moisture + fat $)][$ weight of fibre $] /$
weight of the sample

Where weight of fibre $=$ We-Wa

\subsubsection{Atomic Absorption Spectroscopy}

To measure how much of a given element is present in a sample, one must first establish a basis for comparison using known quantities of that element to produce a calibration curve. To generate this curve, a specific wavelength is selected, and the detector is set to measure only the energy transmitted at that wavelength. As the concentration of the target atom in the sample increases, the absorption will also increase proportionally. A series of samples containing known concentrations of the compound of interest are analyzed, and the corresponding absorbance, which is the inverse percentage of light transmitted, is recorded. The measured absorption at each concentration is then plotted, so that a straight line can then be drawn between the resulting points. From this line, the concentration of the substance under investigation is extrapolated from the substance's absorbance. The use of special light sources and the selection of specific wavelengths allow for the quantitative determination of individual components in a multi element mixture.

Typically, the technique makes use of a flame to atomize the sample, but other atomizers, such as a graphite furnace, are also used.

Three steps are involved in turning a liquid sample into an atomic gas:

1. Desolvation- the liquid solvent is evaporated, and the dry sample remains;

2. Vaporization - the solid sample vaporizes to a gas; and

3. Volatilization - the compounds that compose the sample are broken into free atoms.

\section{RESULTS AND DISCUSSION}

The typical variations in physic-chemical properties estimated before and after drying at $50^{\circ} \mathrm{C}$ were tabulated in Table 2. It can be observed from the table that after drying in fluidized bed drier the physic-chemical properties were varied very small compared to drying in Tray Drier and Hot air oven. The reason may be attributed to effective and uniform removal of moisture in fluidized bed drying due to exposure of entire surface of grain to drying medium. The grain solid structure has not been affected in fluidized bed where as it adversely affected in Hot Air Oven and Tray Drier due to insufficient exposure of grain. Thus, it is found that the size of the grain, density, and porosity increase with decrease in moisture content. Also, the fat content, protein content minerals loss due to drying is minimum when mustard seeds are dried using fluidized bed drier. 
Bhasker V et al., International Journal of Emerging Trends in Engineering Research, 9(4), April 2021, 479 - 484

\subsection{Effect of Temperature on Drying}

As the temperature increases, the drying of the grains also increases. Increasing drying air temperature will increase efficiency on the drying process but there is a practical limitation due to damage of the material caused by the extent of stress cracking. For mustard seeds, the best drying temperature is observed to be not more than $60^{\circ} \mathrm{C}$.

\subsection{Effect of Drying Time}

As the drying time increases, the amount of water evaporated increased. However, it takes less time to reach equilibrium moisture in Hot air oven than in Fluidized Bed Drying. But, in hot oven the seeds are observed to change in their colour on the portion which is having contact with metal surface. It is undesirable and the is not observed in fluidized bed drier even though it takes more time to reach equilibrium moisture in the seeds.

Table 2 Physico-Chemical Parameters of Mustard Seeds

\begin{tabular}{|l|l|l|l|l|}
\hline \multirow{2}{*}{ PARAMETERS } & \multicolumn{4}{|c|}{ MUSTARD SEEDS } \\
\cline { 2 - 5 } & $\begin{array}{l}\text { BEFORE } \\
\text { DRYING }\end{array}$ & $\begin{array}{l}\text { FUIDISED } \\
\text { BED }\end{array}$ & $\begin{array}{l}\text { TRAY } \\
\text { DRIER }\end{array}$ & $\begin{array}{l}\text { HOT } \\
\text { AIR } \\
\text { OVEN }\end{array}$ \\
\hline $\begin{array}{l}\text { Moisture } \\
\text { Percent (\%) }\end{array}$ & 16.5 & 5.98 & 6.84 & 7.10 \\
\hline Size (mm) & 1.66 & 1.98 & 1.95 & 1.87 \\
\hline Density(g/ml) & 1.08 & 1.54 & 1.19 & 1.17 \\
\hline $\begin{array}{l}\text { Bulk Density } \\
\text { (g/ml) }\end{array}$ & 0.72 & 0.79 & 0.76 & 0.74 \\
\hline Porosity (\%) & 33.10 & 43.24 & 39.43 & 37.28 \\
\hline Fat(\%) & 39.7 & 36.5 & 35.9 & 32.5 \\
\hline Ash(\%) & 1.33 & 1.31 & 1.29 & 1.27 \\
\hline Fiber(\%) & 1.82 & 1.80 & 1.78 & 1.76 \\
\hline Protein(\%) & 20.3 & 18 & 17 & 15 \\
\hline Calcium(mg) & 490 & 469 & 425 & 385 \\
\hline Iron(mg) & 7.9 & 7.03 & 5.32 & 5.54 \\
\hline $\begin{array}{l}\text { Phosphorous } \\
\text { (mg) }\end{array}$ & 700 & 663 & 625 & 598 \\
\hline
\end{tabular}

\subsection{Effect Drying Method}

Figure 4 indicates the effect of drying method on drying kinetics. The rate of drying in fluidized bed seems to be more linear compared to other two methods. The removal of moisture during fluidized bed drying is due to diffusion of moisture through grain and through drying medium, hot air. The drying rate was found to increase significantly with increase in temperature and flow rate of the heating medium, while decrease with increase in solids holdup. The duration of constant rate period was found to be insignificant, considering the total duration of drying and kinetics are observed to follow the Newton's exponential decay model.

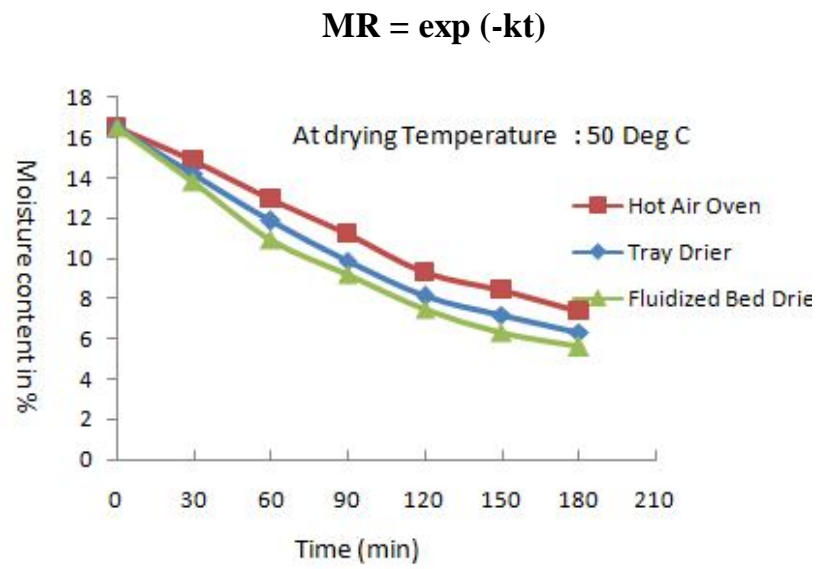

Figure 4 Effect of drying methods on drying kinetics

\subsection{Effect of Fluidizing Medium (Air) Velocity on Drying}

Figure 5 shows the effect of air velocity on drying in Fluidized Bed drying. It is observed that the increased air velocity increases rate of drying and also at given drying conditions, the moisture removal is more for $2.3 \mathrm{~m} / \mathrm{s}$ velocity than for 1.7 $\mathrm{m} / \mathrm{s}$. This may be due to rapid removal of water vapours and enhanced diffusion flux at higher velocity. This predominantly controls the drying kinetics and allows us to monitor the moisture content in the mustard seeds by controlling the air velocity. The optimum air velocity for mustard seeds fluidized bed drying is observed in the experimentation is between $1.5 \mathrm{~m} / \mathrm{s}$ to $2.5 \mathrm{~m} / \mathrm{s}$.

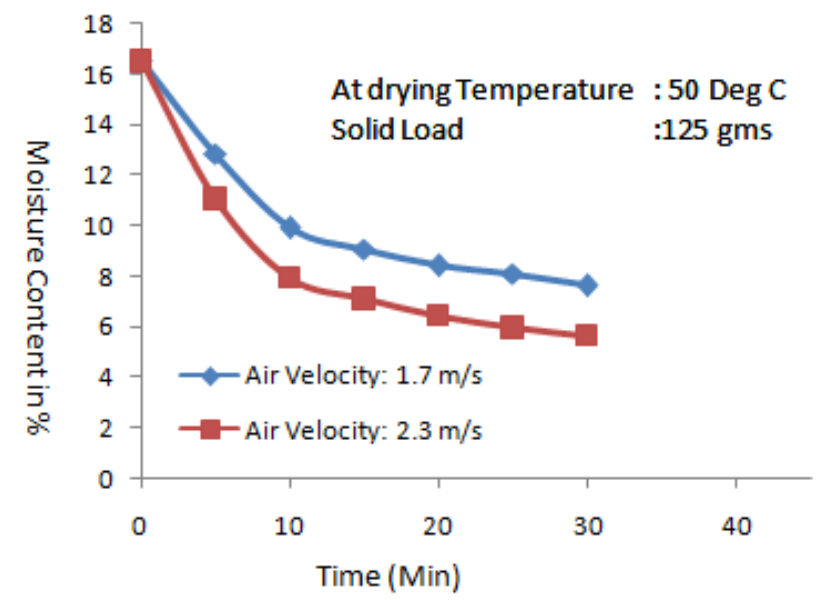

Figure 5: Effect of Drying Medium (Air) Velocity on drying kinetics

\section{CONCLUSION}

Mustard Seeds are to be dried to below 9\% moisture content for safe and long storage. Drying in fluidized bed dryer is very advantageous for safe drying of mustard seeds without losing the nutritional values. Physico-Chemical Properties of Mustard Seeds vary typically during the drying when moisture is being removed. Further, the fluidized bed drying 
method is the best since it minimizes the loss of nutritional values in the grains.

Further, the experimental investigations carried out reveals that the drying rate was found to increase significantly with increase in temperature and velocity of the drying medium, while decrease with increase in solids holdup. The duration of constant rate period was found to be insignificant, considering the total duration of drying. The kinetics of drying was tested with various simple exponential decay models and found to match with Newton's Model.

\section{ACKNOWLEDGEMENT}

The authors glad to acknowledge the financial Assistance offered by UGC-UPE-Focused Area of Research (FAR) Program, Osmania University under subsidiary Research Projects to carry out the present experimental work.

\section{REFERENCES}

1. Okey Francis Obi, Sunday Louis Ezeoha and Chidinma O. Egwu, Evaluation of Air Oven Moisture Content Determination Procedures for Pearl Millet (Pennisetum glaucum L.), International Journal of Food Properties, 19; 454-466, 2016

2. Chandrasekhar Srinivasakannan, Modeling Drying Kinetics of Mustard in Fluidized Bed International Journal of Food Engineering, Volume 4, Issue 32008

3. E. Hajidavalloo, F. Hamdullahpur, Mathematical modeling of simultaneous heat and mass transfer in fluidized bed drying of large particles, in Proceedings of CSME Form; Symposium on Thermal and Fluids Engineering, Toronto, Canada, 19-22, 1988

4. Sandeepa K, Basava Rao V V and Ram Mohan Rao S, Studies on Drying of Sorghum Seeds in a Fluidized Bed Dryer, Proceeding of The $14^{\text {th }}$ International Conference on Fluidization - From Fundamentals to Products, J.A.M. Kuipers, Eindhoven University of Technology, R.F. Mudde, Delft University of Technology J.R. van Ommen, Delft University of Technology N.G. Deen, Eindhoven University of Technology Eds, ECI Symposium Series, 2013

5. Bhasker V and Basava Rao V V, Studies on Fluidized Bed Drying of Millets (Pennisetum Typhoides) International Journal of Engineering and Technology, Volume 8 Issue 3, March 2021

6. K J Simonyan, A M El-Okene and Y D Yiljep, Some Physical Properties of Smaru Sorghum 17, Agricultural Engineering International: the CIGR e Journal Manuscript FP 07008 Volume IX, P. 1 - 14,August 2007 